\title{
The Uncategorized Father: From Self-Manipulation to Self- Creation in Dylan Thomas's Do Not Go Gentle into that Good Night
}

\author{
Rameil Sayad Sangar ${ }^{1^{*}}$, Dr. Hossein Sabouri ${ }^{2}$ \\ ${ }^{1}$ Master of Arts, English Literature, University of Tabriz, Iran \\ ${ }^{2}$ Associate Professor, Department of English, University of Tabriz, 29 Bahman Blvd, Tabriz, East Azerbaijan, \\ Iran
}

*Corresponding Author: Rameil Sayad Sangar, Master of Arts, English Literature, University of Tabriz, Iran

\begin{abstract}
In a letter, Thomas acknowledged that he couldn't show the poem, Do Not Go Gentle Into That Good Night, to his father. The poem was inspired by his aged, hopeless, and dying father. The persona, presumably Thomas himself in real life, brings examples of four types of men who, despite their failures in life, don't go gentle toward death. He does it in order to encourage the dismayed father not to surrender easily to the 'close of day'. Based on Thomas's assertion, the current paper, biographically studies the poem and tries to demonstrate that the frail image Thomas portrays of his father, accompanied by the four ideal characteristics he desires himself and his father to obtain, bolster the specious reasoning in the reader and the persona in their struggle of identification with the self and the other. The study investigates the causes that generate such misrepresentation and propensity for manipulating the other in order to achieve self-identity. Commodification, alienation, anxiety of influence, and capitalism are among the motivators. The study concludes by showing that the floating idealistic images on the surface meaning of the poem, are what Thomas desires his father and himself to acquire before their deaths.
\end{abstract}

Keywords: Dylan Thomas, Alienation, Father, Identity, Image, Self

\section{INTRODUCTION}

Dylan Marlais Thomas (1914-53), was and still is known both for his poetry and his eccentric personality. He started writing poetry when he was still a teenager and later in life he revised much of his youth enthusiastic outbursts which were embellished with the recurrent theme of life and death. His father, an English teacher at Swansea Grammar School, where Dylan himself had his education before leaving school to pursue journalism; his great uncle who was a poet, and also the Welsh bucolic landscapes, were the three inspirations that ignited his fervor for writing. The publication of Deaths and Entrances in 1946 established him as an adroit exploiter of some types of verse forms unfamiliar to English poetry such as villanelle. In his Poetic manifesto, in a pedantic and selfadmiring manner he proclaimed "I am painstaking, conscientious, involved and devious craftsman in words" (Greenblatt, 2012, p. 2698). Poor economic conditions made him to start reading poetry for radio shows and $\mathrm{BBC}$ radio programs with little income, and in spite of his health problems from early childhood when he was diagnosed with Asthma and Bronchitis and later heavy drinking, he initiated poetry reading tours in the United States, which were possible only because of his talent of reading, enchanting voice, and his fame achieved by reading in England. It was his romantic and positive approach of his poems such as Fern Hill, And Death Shall Have No Dominion, and Do Not Go Gentle into That Good Night that raised him to higher attentions in the realm of poetry.

Do Not Go Gentle into That Good Night, published in 1952, one year before Thomas's death, is written in the form of the French villanelle- a fixed form of usually five tercets and a quatrain employing only two rhyme sounds altogether, rhyming aba for the tercets and abaa for the quatrain, with a complex pattern of two refrains (Greenblatt, 2012, p. A27). The poem makes an aged man its audience, advising him to resist and rage against death while he is reaching the end of his life. There's 
this possibility, as revealed in the final stanza, that Thomas wrote the poem to his own ailing father who had become very old and frail at the time of its composition. It can be interpreted as a kind of a confabulation between Thomas and his father in real life as he is trying to transfer the things he wished to say face to face to his father but he couldn't, so eventually he poured out his heart in a mold of a poem. In a letter to Marguerite Caetani he wrote the "only person I can't show the little enclosed poem to is, of course, my father who doesn't know he's dying" (Maud, 2003, p. 77). The poet brings examples of four kinds of men- wise men, good men, wild men, and grave men- and their deeds, achievements, disabilities, and failures in life in order to encourage his own father. Although these men couldn't achieve much in their lives and have left many of their life plans unfulfilled, they never give up hope and surrender easily to death.

\section{FATHER IN LITERATURE}

By being cynical to the reality depicted in the poem, one can doubt the very truth of the infirmness and hopelessness of the father introduced to the reader. After all, how can a person be so forlorn and desperate over death when "he doesn't know he's dying"? It could be claimed that the portrayal of the father in the poem, is in contradiction with the common and frequent representations of fathers in literature. The fathers are most commonly known as being the symbol of courage, heroism, supervision, suppression, and even despotism. The Renaissance father, be it malign or benign, for instance, in the plays of William Shakespeare as seen in Hamlet, even after his death, in the form of a ghost, is filled with rage and revenge. Sir Thomas More, Lord Chancellor to Henry VIII, never yields to make oath and to sign the document to authorize King Henry as the supreme leader of England's Church to separate from the authority of Catholic Rome which would enable him to divorce his queen and seek another marriage with the hope of having a male heir to his throne. Eventually, the resisting More was found guilty of high treason and was sentenced to death, leaving his children fatherless. In A Man for All Seasons (1954), a play by Robert Bolt, before his execution, More announces:

I am the king's true subject, and I pray for him and all the realm. I do none harm. I say none harm. I think none harm. And if this be not enough to keep a man alive, then in good faith, I long not to live. Nevertheless, it is not for the Supremacy that you have sought my blood, but because I would not bend to the marriage! (II. 60-61)

The postmodern literary father in the novel The Road (2006) by Cormac McCarthy, is also capable of showing noble qualities at dire times when the world is overwhelmed with the most inhumane conditions. The story is set in an annihilated post-Apocalyptic landscape in the United States where natural resources are depleted, everywhere is burned, and many have turned to cannibalism. In such a world the father fiercely struggles to stay in the band of "good guys" and to keep his child alive. Though experiencing horrible events, he doesn't succumb and is importunate to reach the coast in south to save his son. He fulfills what he set to accomplish but meets his own death in the end out of illness and fatigue.

What is being perceived in Do Not Go Gentle into That Good Night is a weak and disheartened father who waits for his death while is being advised by his own son. The paradox here is the opposition in the Freudian Oedipal system. Usually it's the parent who give advises or discipline their children. By introducing the four types of old men "he does give a sense that he has priorities as to how life can be lived" (Napierkowski, 1997, p. 53). If Thomas is considered as the admonishing son in the poem, the reprimanding Thomas himself, ironically died a year after his father. Thomas precipitated his own death by heavy drinking leading to fatal health problems which in its own turn draw him to heavy monetary debts. His alcoholism was the exact cause of his death in New York in 1953 diagnosed as "an insult to the brain" (Greenblatt, 2012, p. 2698). The question is, did he himself go gentle into that good night?

\section{IMPERFECTION AS A SIGN OF LOVE}

The purpose from bringing the examples of the literary fathers is to show that old men are mostly known for their experience, wisdom, and fearlessness who don't mind the materialistic and worldly matters at the time of death, unless they are greedy. There is no doubt about the love Thomas has for 
his father, though he is imperfect and lacks some features. Thomas doesn't include his father within the four categories he introduces. He is none of what he mentions. He is not a wise, a good, a wild, and a grave man. If he were, he wouldn't embrace death so desperately. Thomas encourages his father, by being full of rage and anger, to rebel and overthrow the weakness he shows at the moment of death. Anger which "is much more of a young man's emotion than an old man's" (Napierkowski, 1997, p. 53). By this, he portrays a "young man's unreasonable and hysterical refusal to accept the sad weakness of his father" (53). Thomas somehow decategorizes his own father. The problem would be solved if the father could effectively comprise himself in one of these four categories. Thomas's father lacks courage and rage and this lack of something in him, according to Slavoj Žižek (2015) is the exact reason that someone loves another person or another thing. It doesn't mean that if the father were flawless and complete, the son would hate him or the father would become one of those cruel father figures that the son would wish to exterminate. In his online interview, Synthetic Sex and Being Yourself, Žižek comments on the problems he sees in online dating stating that:

It always automatically involves this aspect of self-commodification or self-manipulation. When you date online you have to present yourself there in a certain way, putting forward certain qualities. You present an image of yourself and you focus on your idea of how other people should perceive you. (Youtube)

Thomas defined poetry as a stimulator of emotions which "makes you laugh, cry, prickle, be silent, makes your toe nails twinkle," a reason to take action that "makes you want to do this or that or nothing" and an existential cause which "makes you know that you are alone in the unknown world, that your bliss and suffering is forever shared and forever all your own" (Babusci, 1991, p. 584). According to this definition of poetry with its multifunctional aspects, in which the poet has the power to control all the readers' emotions, actions, and life, it is not impertinent to make a resembling connection between poetry and the internet as being two forms of figurative spaces that in the former space, the semi-present persona and the reader establish a correspondence which affects the feelings and other faculties, while in the latter, the online daters in order to attract their net counterparts go through self-commodification or self-manipulation. Since in the internet, it is optional for people to change their identities and devise whatever personality and physiognomy they desire to acquire and depict, it's not unexpected that a poet in a poem predetermines to change some facts in order to represent his own idea of the world. For Žižek (2008) "poetry is always, by definition, "about" something that cannot be addressed directly, only alluded to" (5), in this sense it is not the father who self-manipulates but it is the son, the poet, who by allusion to other figures, manipulates the character of his father to make him lack something so according to Žižek becomes an object petit a. This is somehow related to Harold Bloom's theory, the 'anxiety of influence'. Continuing on how love functions, Žižek (2015) declares:

The so called English term "endearing foibles" means that you cannot ever fall in love with a perfect person. There must be some tiny disturbing element and it is only through noticing this element that you say in spite of that imperfection I love him or her. (Synthetic Sex and Being Yourself)

Valor is an excess which is interpreted by the son as a lack, which is a sign of imperfection. It is beautifully manipulated by Thomas in the poem. He clearly envies the four types of men he names, because they don't go gentle towards death. But it is the imperfect father whom he dearly loves, a love engendered by his acquisition of imperfection. Resistance, rage, and hope are some excessive imagined qualities that the four men have but the father lacks. If the father were effectively to lose his hopelessness and timidity, he wouldn't be perfect. In Žižek's (2015) words:

The illusion of perfection is created precisely by this excess. It's too much but then you imagine that without this it would have been perfect. If you take away this excess you don't get perfection. This is what in psychoanalytic theory we call "object cause of desire", not "object of desire", object of desire in this case is any person. But the cause of desire, in the sense of what makes you fall in love is always a sign of imperfection. (Synthetic Sex and Being Yourself) 


\section{FROM THE OTHER TO THE SELF}

It is noticeable that the [self]manipulation discussed earlier is very much congruous with Bloom's sub-theory of 'misreading' or 'misprision' (misunderstanding) in his theory of 'anxiety of influence'. For Bloom "we are belated sons who will never be as great as our fathers, but it is death for us to admit that we are inferior" (Leitch, 2010, p. 1648). Bloom's major source in developing this idea is Sigmund Freud's "oedipal conflict between sons and fathers" (1648) that guides him to his theory of the anxiety of influence which for him is the "vision of our necessarily ambivalent relation to literary ancestors" (1648). For Bloom, the poet son, is influenced in all aspects by the work of his beloved trailblazer whom he desires to overcome, by far "a poet's world and aims are shaped by the words of the precursors he most admires, the project of self-creation requires the denial of all influence, a "misprision" of his actual sources" (1649).

Bloom asserts that the latecomer seeks originality for which a fundamental requirement is aggression in order to achieve reverence and in Thomas's case the desire for aggression is perceivable in the form of rage. The process of fulfilling this originality goes through six stages which Bloom calls "six revisionary ratios" that "each represents a strategy enabling the latecomer to revise the previous poet while either denying influence or professing reverence" (1649).

Thomas's father and great uncle cherished poetry and tried their hands in writing it too. Dylan's life for his scholars "appeared to be an attempt to realize his father's frustrated dream of being a great poet" (Napierkowski, 1997, p. 50) and in a same fashion Bloom (1997) states that "every poet begins (however "unconsciously") by rebelling more strongly against the consciousness of death's necessity than all other men and women do" (10). This attempt for Charles I. Knauber is an "individual struggle from darkness towards some measure of light" (Napierkowski, 1997, p. 59). Thomas strives to exchange the reality of the aged man's nature in his poem with the self-proclaimed fantasy of presupposed impossible perfection of his precursor. Thomas knows that the precursor is aware of his inability to fulfill such a quest for perfection, and Thomas deliberately exposes this disability, what Žižek (2015) calls foible, in order to cover his own foibles and maintain his own reverence as Vincent B. Leitch (2010) declares "in his impossible quest to achieve immortality, the strong poet strives to replace nature with art and previous poems with his own work, thereby declaring himself self-created and the master of his own fate" (1649).

This quest of the achieving self-reverence by the latecomer cannot be accomplished by mere imitation or repetition of the precursor's work, because to "imagine [a poem and a self] is to misinterpret, which makes all poems antithetical to their precursors" (Bloom, 1997, p. 93). As Leitch (2010) comments on Bloom's theory "every poem rewrites earlier poems; every poem is an interpretation. Only misinterpretation of precursor affords the poet his own voice, his own distinctive existence" (1649).

Bloom (1997) writes that "Freud's investigations of the mechanisms of defense and their ambivalent functionings provide the clearest analogues" he has "found for the revisionary ratios that govern intrapoetic relations" (8). This ambivalence in father-son relationship is considerably detectable and a recurrent theme in Thomas's poetry, but in Do Not Go Gentle into that Good Night, Thomas turns this theme all over to its head. Jhan Hochman tracks these ambivalent feelings in some of his poems. He compares Do Not Go Gentle into that Good Night with poems such as I See the Boys of Summer, Find Meat on Bones, and Elegy in which on the contrary, it is the father who condemns the younger, urges the youth to rebel, and is a father who is kind, brave, and too proud to cry (Napierkowski, 1997). Do Not Go Gentle into that Good Night, in a form of an advice, is "offered more for the benefit of Thomas himself than for his father" (58). Thomas consequently misreads or misinterprets the existence of his father in such a way that better suits him. For Bloom (1997), this stage is called Clinamen, "which is poetic misreading or misprision proper" (14) and also according to Žižek's manipulation concept, brings about the imperfection and disturbing elements that causes Thomas to endear his father. In the poem, which is considered as an autobiographical entity, Thomas somehow tries to impair his father so he can cover his own failures and shortages. This is the third stage of Bloom's theory and is called Kenosis, "where the precursor was, there the ephebe shall be, but by the discontinuous mode of emptying the precursor of his divinity, while appearing to empty himself of his own (1997, p. 91). Thomas does it in order to normalize imperfection as a universal category and to take refuge under his fathers' imperfection, and to endear his own foibles which are alcoholism, physical and health problems, and financial debts. Thomas's poem, ultimately, with a eulogistic 
dexterity in composition, procreates a bilateral system of endearing of the self and the other, which makes love and sympathy both for the father and the son practicable.

\section{Alienation ANd RECOVERING THE SELF}

It's nightmare, night \& day; there never was such a place; I could never get used to the speed, the noise, the utter indifference of the crowds, the frightening politeness of the intellectuals, and, most of all, these huge phallic towers, up \& up \& up, hundreds of floors, into the impossible sky. I feel so terrified of this place, I hardly dare to leave my hotel room. (Christie, 2014, p. 158)

Nightmare was the major constituent of what built up the final four embittered years of Dylan's life from 1950 to 1953 when he moved to the United States hoping to meet "any chance of getting a job" (Christie, 2014, p.156). The fragmentation burgeoned out of the speed and the noise of life in the megacity of New York, the alienation of social life risen out of the utter indifference of the crowds, the political correctness implied by the frightening politeness of the intellectuals, and the industrialized and commodified fashion of the big city were what pushed Dylan into his terrified and alienated self in his solitary thirtieth floor room in Manhattan. These were the conditions which made him incessantly feel a "prolonged confusion and deepening depression" (156) and also made sleeping at nights impossible for him without taking drugs and heavy doses of drinks (158).

Readings of poetry in many university campuses and public places of the United States had promised a large sum of money to this great Welsh and universally admired poet, but ultimately left him even more destitute and his "American dream seemed to have turned very quickly into an American nightmare" (157). Philip Burton, a theatre director and radio producer approached Dylan on his last day in London saying, "Why are you going to America Dylan?" and he said "To make money!" And I said, "How much will you bring back?" And he smiled and said, "Not a cent". He knew what he was doing but couldn't resist doing it'(163).

"I have no idea what on earth I am doing here in the very loud, mad middle of the last mad Empire on earth" (157), wrote Dylan to his wife from his hotel room in Manhattan. Burton's claim that Dylan "knew what he was doing but he couldn't resist doing it" is in total contradiction with Dylan's own statement that "I have no idea what on earth I am doing here." The problem lies somewhere between the illusion of having the knowledge and illusion in the reality of doing something which both are the fruits of alienation and reification. To put it in Žižek's (2008) phrasing, it reads: "they know that, in their activity, they are following an illusion, but still, they are doing it" (30). György Lukács in his History and Class Consciousness (1923) develops his concept of 'reification' which is a synthesis of different ideas of Marx, Weber, and Hegel. In capitalist societies, it is a process that pushes people and human relations in social life to the status of things and views them mutable things with price tags as a result of commodification generated from different modes of commodity production and fetishism of commodity (Leitch, 2010). Lukács argues that reification:

stamps its imprint upon the whole consciousness of man; his qualities and abilities are no longer an organic part of his personality, they are things which he can 'own' or 'dispose of' like the various objects of the external world. And there is no natural form in which human relations can be cast, no way in which man can bring his physical and psychic 'qualities' into play without their being subjected increasingly to this reifying process. (Livingstone, 1967, p. 100)

Žižek (2007) believes that in capitalism "the relationship between an object and its symbol-image is inverted: the image does not represent the product, but, rather, the product represents the image" (228). This is in direct parallelism with what he calls "commodification of experiences" (229) which requires people to detect behind and between the things, the social relations between human subjects. The example Žižek brings is that of the organic apple. When we buy organic apples we don't really trust in and believe that those half rotten apples are any better that the genetically improved apples, but we are participating in a cultural trend and lifestyle that indicates healthiness and environmentally friendly shopping that has not involved soil fertilizer in itself, which is harmful to our mother earth (229). This is what is called 'cultural capitalism' (228). In other words, the things people buy on the market are more about life experiences than being about the products they really want to own. When 
Dylan replied "not a cent" to the question of how much money will he bring back to his family after his work is done in the U.S., he already knew that he will not bring back any cent, except his own nightmarish experiences. As William Christie said, "It should never be forgotten that America was also a liberating, alcoholic distraction for Thomas... America the fatal temptress... a manic circuit of poems, booze, and women" (2014, p. 169). Dylan in the poem itself brings life experiences of other types of men, "the poem seems to have selected them out of dozens of possibilities as being the only lifestyles that are worth serious consideration" (Napierkowski, 1997, p. 53).

The father's alienation in the sense of reification which is a content "effectively the product of the subject's (collective) activity is falsely experienced as an autonomous entity which controls the subject, so that, in the act of liberation, the subject should reappropriate to itself its alienated substance, recognize in it its own product" (Žižek, 2016, n.p.) is also accompanied by the son's alienation in the sense of the "individual subject alienated from its social substance, experiencing itself as a singularity which confronts an alien world" (n.p.). The reified father is perceived as a thing or a commodity which in Marxian terminology has an "exchange value" and can be compared to other types of old men and is desired to be reappropriated to a character similar to the four men and to regain his presumed alienated substance. Prior to this reification of the father, is the alienation of Dylan himself who confronts an alien world. He is terrified and takes refuge in his hotel room which he dares not to leave. According to Knauber (1954), "Thomas attempts to comprehend the mystery of life's reality in order that his world might be made more acceptable. He is incapable of creating an escape from reality, for, on this level, the real world is his only sphere" (Napierkowski, 1997, p. 59).

To escape from this reality, the speaker strives to establish an idealized identity by means of symbolic identification. Žižek (2008) argues that "to achieve self-identity, the subject must identify himself with the imaginary other, he must alienate himself - put his identity outside himself, so to speak, into the image of his double" (116). What this could mean in the context of the poem is that Thomas by using the examples of the four types of old men from the persona's point of view, "reveals ideals of what he would like to be before death" (Napierkowski, 1997, p. 54). The identity he tries to build for the ailing father is the exact identity he tries to obtain for himself, but as Žižek argued he has to alienate himself and put his identity outside, into the image of his double, since he is terrified of the reality of his world and he does it in the form of an escape. The father, as a double, functions as a sign and a simulation. It signifies what Dylan himself tries to be in the real world i.e. being wise, good, wild, and brave. This form of simulation from the perspective of Gary Leonard, in a way, "exist in order to posit the illusion of a reality that is elsewhere. Disney World, for example, is, according to Baudrillard, an aggressively 'simulated' world serving to help make the rest of 'America' seem real" (Wolfreys, 2006, p. 285-286).

For Baudrillard, modernity is defined by the intricate involvement of society in the market, commodity production, and consumerism, and postmodernism on the other hand, is distinguished by the conquest of simulation, images, and signs over the real (https://plato.stanford.edu), making what Baudrillard calls 'hyperreal'. He calls this hyperreal function of signs 'simulacrum' (Leitch, 2010, p. 1554). What it denotes is that the real has been replaced by the signs and when it happens, the signs don't refer to what they signify properly and consequently as Kellner Douglas (2007) argued, "in the society of simulation, identities are constructed by the appropriation of images, and codes and models determine how individuals perceive themselves and relate to other people" (https://plato.stanford.edu). Similarly in the poem the dying father, for Thomas, doesn't signify what a real old man should be. His idea of a perfect father and the character he really desires to be, is instigated by the hyperreality, signs, and images of a standard father, who is shaped by cultural and societal discourses.

This shift is compatible with Žižek's (2007) argument in his critique of capitalism that the image does not represent the product (228). Baudrillard prior to Žižek, figured out the bizarre functioning of the market in production of commodities and as Leitch (2010) comments on Baurillard's theory, "capitalist production in our times proceeds by first creating a demand through marketing and then producing the product to meet the demand" (1554). This means that the "world is remade in the image of our desires. The signs (the images of what we want) exist before we create the thing to which the sign refers" (1554). Thomas's representation of an ideal raging father, which is an amalgam of four 
noble behaviors that he desires his father to acquire, doesn't have a real subsistence. What an image of an ideal father signifies for Thomas, is someone who sustains some certain qualities i.e. wisdom, goodness, wildness, and graveness, but he appears to be none, at least in his old age. These precoded qualities are what Thomas demands in a father when their totality doesn't have an actual existence in the father's real life. The real father sitting on the "sad height," in Baudrillardian understanding, "does not exist beyond the presumption of its existence as the basis of the representation" (Wolfreys, 2006, p. 287), but represents the conceptual image of an ideal old man he wants to become before his own death.

\section{CONCLUSION}

Jean-Jacques Rousseau writes in Confessions "there are times when I so little resemble myself, that one would take me for another man of quite an opposite character" (1904, p. 115) alluding to his wavering personalities in his life, so much the same as Walt Whitman who in Song of Myself professes "I am of old and young, of the foolish as much as the wise, regardless of others, ever regardful of others, maternal as well as paternal, a child as well as a man" (Baym, 2012, p. 1341). This alienation of the self into an imagery other self, is what it takes to build an ideal desired selfidentity, similar to the inclination of human beings to have a public self and a real self in their privacy. The dying father may or may not be as weak as Thomas tells the reader. He is being encouraged by his son to be whether wise, good, wild, or grave at the time of his death. Thomas by using the examples of the four types of men from the persona's point of view, tries to refuse the weakness of his father and to make that ideal image and identity he tries to obtain before his own death. In the current paper, biographical probations and the applied theories likewise, have proven to be capable of directing the study towards the purpose of it. Due to the large amount of literature that exists on Dylan Thomas's work, the reader is suggested to have further studies in any case of interest.

\section{REFERENCES}

[1] Greenblatt, S. The Norton Anthology of English Literature. $\left(9^{\text {th }}\right.$ ed.). New York: W. W. Norton \& Company, Inc, 2012.

[2] Maud, R. Where Have the Old Words Got Me: Explications of Dylan Thomas's Collected Poems (1 ${ }^{\text {st }}$ ed.). McGill-Queen's University Press, 2003.

[3] Bolt, R. A Man for All Seasons. [Online] Available: https://docs.google.com/viewer?a=v\&pid=sites\& srcid=cG5kaHMub3JnfHNyLWNhdGhlcmluZS10aG9tYXMtb3AtdGhlb2xvZ318Z3g6NzYzNTg4ZjQ0Y mFhMDQyOA

[4] Napierkowski, M. R. Poetry for Students. (Book 1). Gale, 1997.

[5] Žižek, S. Synthetic Sex and Being Yourself. [Video file] Available: https://www.youtube.com/watch? v=7xYO-VMZUGo (June 7, 2015)

[6] Babusci, R. Prentice Hall Literature: Platinum. (2 ${ }^{\text {nd }}$ ed.). Pearson Prentice Hall, 1991.

[7] Žižek, S. Violence. ( ( $^{\text {st }}$ ed.). New York: Picador, 2008.

[8] Leitch, V. B. (Gen Ed.). The Norton Anthology of Theory and Criticism. ( ${ }^{\text {nd }}$ ed.). New York: W. W. Norton \& Company, Inc, 2010.

[9] Bloom, H. The Anxiety of Influence: A Theory of Poetry. ( $2^{\text {nd }}$ ed.). New York: Oxford University Press, 1997.

[10] Žižek, S. The Sublime Oobject of Ideology. ( $2^{\text {nd }}$ ed.). London: Verso, 2008.

[11] Christie, W. Dylan Thomas: A Literary Life. (1 $1^{\text {st }}$ ed.). Hampshire: Palgrave Macmillan, 2014.

[12] Lukács, G. History and Class Consciousness: Studies in Marxist Dialectics. Translated by Livingstone, R. MIT Press Edition, 1972. (Original work published 1923)

[13] Žižek, S. The Universal Exception. (Paperback ed.). London: Continuum, 2007.

[14] Žižek, S. Disparities. (Pdf ed.). Bloomsbury Academic, 2016.

[15] Wolfreys, J. Modern European Criticism and Theory: A Critical Guide. (2 ${ }^{\text {nd }}$ ed.). Edinburgh: Edinburgh University Press, 2006.

[16] Kellner, D. Jean Baudrillard. (Winter 2015 Ed.). [Online] Available: https://plato.stanford.edu/cgibin/encyclopedia/archinfo.cgi?entry=baudrillard

[17] Rousseau, J. J. Confessions. Translated by Rhys, E. Everyman's Library, 1904. (Original work published 1782) 
[18] Baym, N. (Gen Ed.). The Norton Anthology of American Literature. (8 $8^{\text {th }}$ ed.). New York: W. W. Norton \& Company, Inc, 2012.

\section{AUTHOR'S BIOGRAPHY}

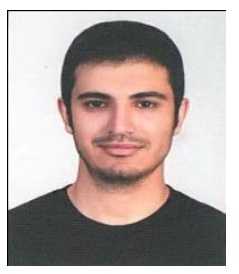

Rameil Sayad Sangar, M.A. in English Literature and Language. He earned his Bachelor's degree in English Literature and Language from Urmia University and his Master's degree from University of Tabriz.

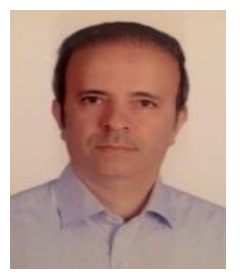

Dr. Hossein Sabouri, Associate Professor, University of Tabriz. He received his $\mathrm{PhD}$ in English Literature and Language from Punjab University Chandigarh. He has been teaching English Literature and Language in University of Tabriz since 2004 andhas published many articles and books including English Poetry: From Renaissance to T. S. Eliot.

Citation: Rameil Sayad Sangar, Dr. Hossein Sabouri. “The Uncategorized Father: From Self-Manipulation to Self-Creation in Dylan Thomas's Do Not Go Gentle into that Good Night" International Journal on Studies in English Language and Literature (IJSELL), vol 6, no. 5, 2018, pp. 1-8. doi:http://dx.doi.org/10.20431/23473134.0605001 .

Copyright: (C) 2018 Authors. This is an open-access article distributed under the terms of the Creative Commons Attribution License, which permits unrestricted use, distribution, and reproduction in any medium, provided the original author and source are credited. 